\title{
Effect of Rabbit Production Factors on Revenue of Rabbit Farmers in Berastagi District, Karo Regency
}

\author{
M Bayu, S Umar, Hasnudi, N Ginting, Y L Henuk \\ Animal Production Program Study, Faculty of Agriculture, University of North \\ Sumatera, \\ Medan 20155, Indonesia \\ E-mail: bayu.avenger.a7x@gmail.com
}

\begin{abstract}
The aim of this research was to investigate the influence of rabbit production factors on rabbit farmers income in the District of Berastagi Regency of Karo which include Litter Size, Sum of Wean, Sum of Deaths, Feed Cost and Sum of Labor; and knowing rabbit business in District of Berastagi Regency of Karo is deserves to be forwarded. The research method used census method done twice for two months to take as many as 48 respondent farmers. Factor analysis was obtained by regression analysis while business feasibility obtained by Revenue Cost Ratio (Ratio R/C), Benefit Cost Ratio (Rasio B/C) and Break Event Point (BEP) analysis. The results showed that the factor affect rabbit farmers income were Sum of Deaths and Sum of Labor. Financial analysis of rabbit farmers were $\mathrm{R} / \mathrm{C}=5,61, \mathrm{~B} / \mathrm{C}=4,24$, Price $\mathrm{BEP}=\mathrm{Rp} 9.875$ dan Production $\mathrm{BEP}=22$ pieces. It conclude that the factor affect rabbit farmers income were Sum of Death and Sum of Labor. Rabbit business is profitable and feasible to conduct.
\end{abstract}

\section{Introduction}

The reproductive appearance of rabbits that are good and considered normal, among others, namely, at the age of four months, rabbits can reach sexual maturity and can be mated with 8-10 females with $95 \%$ success rate of fertilization. The length of rabbit pregnant is 31-32 days on average, the average number of children per birth is 6-7 with a safety level of $85-95 \%$, the rabbit is weaned by the mother at an average age of 6-8 weeks, immediately after giving birth, the rabbit can mated again Cheeke et.al., [1].

Success in a livestock business can only be achieved if the supporting factors receive full attention. One of the main factors is food besides genetics and management. Therefore, good and superior breeds must be balanced with good food Ensminger [2].

The ultimate goal of livestock farming is sales or marketing. With the sale or marketing, the farmer will get income that will be able to help him in fulfilling his life needs and his family. According to Key and Edward [4], income is revenue which is reduced by production costs.

One of the locations of rabbit farms that is widely known as a producer of rabbit livestock is Berastagi District. The population of rabbits in this region is relatively large. Many breeders or rabbit collectors residing in Medan, Binjai, Tanjung Morawa, Pancur Batu and other areas who bought rabbits in Berastagi for resale. The aim of the study was to determine the effect of rabbit production factors on rabbit breeders' income in Berastagi District, Karo Regency which included litter size, weaning number and number of deaths and the cost of feed and number of workers and to know that rabbit farming in Berastagi District, Karo Regency was feasible. 


\section{Materials and Methods}

\subsection{Place and time of research}

This research was conducted at a rabbit farm in the District of Berastagi, Karo, North Sumatra Province for approximately 2 months, from August to September.

\subsection{Types of research}

The method used is a survey method by means of census where data is taken from the entire population of rabbit farmers in Berastagi District, Karo Regency. Census is a sampling technique if all members of the population are used as samples Sugiono [5]. The number of rabbit breeders in Berastagi District, Karo Regency is 48 breeders.

\subsection{Location Selection}

This research was conducted at a rabbit farm located in Berastagi District, Karo Regency. The location of this study was chosen by purposive random sampling method, which is a method of deliberately determining the location of research, with the reason that Berastagi District is the center of rabbit farms in Karo Regency.

\subsection{Data Collecting}

The data collected in the implementation of this study consisted of Primary and Secondary data: Primary data were obtained directly from rabbit farmers using the interview method through filling in the questionnaire (questionnaire). Secondary data was obtained from various agencies and agencies related to this study and the literature related to this study.'

\subsection{Data analysis}

To get results from the analysis of income for rabbit breeding activities, obtained by the formula :

Information: $\mathrm{Pd}=\mathrm{TR}-\mathrm{TC}$

$\mathrm{Pd}=$ Disposible income or benefits obtained by rabbit farmers $(\mathrm{Rp})$

$\mathrm{TR}=$ Total cost or receipt obtained by rabbit breeders $(\mathrm{Rp})$

$\mathrm{TC}=$ Costs incurred by rabbit farmers $(\mathrm{Rp})$

Whereas to get the total receipt (TR) formula is used:

$$
\mathrm{TR}=\mathrm{Py} \text {. } \mathrm{Y}
$$

Information:

$\mathrm{TR}=$ Total cost or receipt obtained by rabbit breeders $(\mathrm{Rp})$

Py $=$ Selling price $(\mathrm{Rp})$

$\mathrm{Y}=$ Amount of production sold (ekor)

Based on the results obtained, then to see whether rabbit production factors including litter size, weaning number and rabbit child mortality and feed costs and labor costs have an effect on income can be seen with the Econometry technique approach model using multiple linear regression analysis, that is :

$$
\hat{\mathrm{Y}}=\mathrm{a}+\mathrm{b} 1 \mathrm{X} 1+\mathrm{b} 2 \mathrm{X} 2+\mathrm{b} 3 \mathrm{X} 3+\mathrm{b}_{4} \mathrm{X}_{4}+\mathrm{b}_{5} \mathrm{X}_{5}+\pi
$$

To identify the second problem, the data analysis method used is the method of analysis of Revenue Cost Ratio, Benefit Cost Ratio and Break Event Point (BEP). Analysis of Revenue Cost Ratio, or known as the ratio (ratio) between revenue and cost, can be mathematically written :

$$
\begin{aligned}
& \mathrm{A}=\mathrm{R} / \mathrm{C} \\
& \mathrm{R}=\mathrm{Py} . \mathrm{Y} \\
& \mathrm{C}=\mathrm{FC}+\mathrm{VC} \\
& \{\mathrm{A}=(\mathrm{Py} . \mathrm{Y}) /(\mathrm{FC}+\mathrm{VC})\}
\end{aligned}
$$


To see how much benefits a business generates, it is necessary to analyze Benefit Cost Ratio or what is known as the ratio between income and total production costs, mathematically can be written :

$\mathrm{b}=\mathrm{B} / \mathrm{C}$ 
To see the Break Event Point (BEP) at the production level and price in rabbit farming business can be calculated using a formula :

$$
\begin{aligned}
\text { BEP Production }= & \text { Total Cost }(\mathrm{TC}) \\
\text { BEP Price }= & \begin{array}{c}
\text { Price of Sales }(\mathrm{Py}) \\
\text { Total Cost }(\mathrm{TC})
\end{array} \\
& \text { - Production Price }(\mathrm{y})
\end{aligned}
$$

\section{Results and Discussion}

\subsection{Litter Size}

The composition of the Litter Size is between 2-13 kits, which are presented in Table 1.

Table 1. Litter Size Composition of Rabbit Farmers Respondents

\begin{tabular}{lccc}
\hline \multicolumn{1}{c}{ No. } & Litter Size (tail) & Amount (people) & Percent (\%) \\
\hline 1 & $1-3$ & 5 & 10,41 \\
2 & $4-6$ & 24 & 50,00 \\
3 & $7-9$ & 14 & 29,16 \\
4 & $\geq 10$ & 5 & 10,41 \\
\hline Total & 48 & 100 \\
\hline Average & & 25 \\
\hline
\end{tabular}

Table 1 shows that $50 \%$ of rabbit breeders have 4-6 rabbit size litters, this indicates that the rabbit's litter size is not too low and also not too high which will make the rabbit weaning is quite high. Hernawati [3] states the litter size depends on the nation, food, age and environment or parent condition. While the average is $25 \%$.

\subsection{Sum Of Wean}

The composition of weaning amounts between 2-13 tails, which are presented in Table 2 .

Table 2. The Composition of Rabbit Wean Farmers Respondents

\begin{tabular}{lccc}
\hline No. & Litter Size (tail) & Amount (people) & Percent (\%) \\
\hline 1 & $1-3$ & 7 & 14,58 \\
2 & $4-6$ & 28 & 58,33 \\
3 & $7-9$ & 10 & 20,83 \\
4 & $\geq 10$ & 3 & 6,25 \\
\hline Total & & 48 & 100 \\
\hline Average & & & 25 \\
\hline
\end{tabular}

Table 2 shows that $58.33 \%$ of rabbit breeders have $4-6$ rabbits, this indicates that the sum of rabbits weaning is quite high, so there will be many rabbits that can be sold. While the average is $25 \%$. 


\subsection{Sum of Deaths}

The composition of sum of rabbit deaths is between 1-3 tail, which is presented in Table 3.

Table 3. The Composition of Rabbit Death Farmers Respondents

\begin{tabular}{lccc}
\hline \multicolumn{1}{c}{ No. } & Litter Size (tail) & Amount (people) & Percent $(\%)$ \\
\hline 1 & $1-3$ & 43 & 89,58 \\
2 & $4-6$ & 5 & 10,41 \\
3 & $7-9$ & - & - \\
4 & $\geq 10$ & - & - \\
\hline Total & & 48 & 100 \\
\hline Average & & & 50 \\
\hline
\end{tabular}

Table 3 shows $89.58 \%$ of rabbit breeders have 1-3 rabbit mortality, this indicates that the mortality rate of rabbits is relatively small so that many rabbits can survive which farmers can later sell. But even so, this cannot be ignored because it involves rabbit deaths which can harm the rabbit farmer's respondents themselves by looking at an average of $50 \%$.

\subsection{Feed Costs}

The cost composition of rabbit feed is between Rp. 0-100,000, which is presented in Table 4.

Table 4. Cost Composition of Rabbit Feed Respondents of Rabbit Farmers

\begin{tabular}{lccc}
\hline No. & Feed Costs (Rp) & Amount (people) & Percent $(\%)$ \\
\hline 1 & 0 & 29 & 60,41 \\
2 & 20.000 & 1 & 02,08 \\
3 & 30.000 & 1 & 02,08 \\
4 & 40.000 & 2 & 04,16 \\
5 & 50.000 & 8 & 16,66 \\
6 & 60.000 & 2 & 04,16 \\
7 & 75.000 & 2 & 04,16 \\
8 & 80.000 & 1 & 02,08 \\
9 & 100.000 & 2 & 04,16 \\
\hline Total & & 48 & 100 \\
\hline Average & & & 11,11 \\
\hline
\end{tabular}

Table 4 shows that $39.59 \%$ of rabbit breeders had Rp. 20,000 - 100,000 in feed costs, this indicates that most farmers did not spend their daily feed costs because rabbit feed was very much available there. The availability of feed can be seen from the average obtained, which is $4.95 \%$ of $39.59 \%$ of the rabbit farmer respondents who have Rp. 20,000-100,000 feed costs. Of the $60.41 \%$ respondents rabbit breeders who have Rp. 0 the cost of feed, basically still has the cost of feed which is shown from the average obtained which is $11.11 \%$.

\subsection{Sum of Labor}

The composition of the sum of labor is between 0-3 people, which are presented in Table 5.

Table 5. Composition of Number of Workers in Rabbit Farmers Respondents of Rabbit Farmers

\begin{tabular}{lccc}
\hline No. & Total Manpower (people) & Amount (people) & Percent (\%) \\
\hline 1 & 0 & 33 & 68,75 \\
2 & 1 & 13 & 27,08 \\
3 & 2 & 2 & 04,16 \\
4 & 3 & 0 & 00,00 \\
\hline Total & 48 & 100 \\
\hline
\end{tabular}


Table 5 shows that $31.25 \%$ of rabbit breeders have 1-3 workers, this shows that most farmers do not have labor because it is not too difficult to take care of rabbits. However, if it is observed from $68.75 \%$ of rabbit breeders who do not have workers, basically they still have workers, namely the breeders themselves, which is indicated by the average obtained, which is $33.33 \%$. This is based on the costs incurred to fulfill their daily needs because their income is only from raising these rabbits.

\subsection{Multiple Breeders Regression Analysis}

By using multiple regression equations, a rabbit breeder equation function is formed. The variables that are considered to have an influence on the income of rabbit farmers are litter size (X1), weaning amount (X2), death (X3), feed cost (X4) and the amount of labor (X5). All of these variables are simultaneously entered into multiple regression equations, the following results are obtained:

$$
\mathrm{Y}=2.475 \mathrm{E} 6 \text { + 95853.004X1 + 425278.608X2 - 1.534E6X3 + 4.913X4 + 2.570E6X5 + } \pi
$$

Table 6. The Results of Multiple Breeders Regression Analysis About the Effect of Factors of Rabbit Breeder Production on Revenue

\begin{tabular}{lcccc}
\hline \multicolumn{1}{r}{ Variable } & Coefficient & t-count & Significant & Information \\
\hline Constant & $2.475 \mathrm{E} 6$ & 2.889 & .006 & tn \\
Litter Size & 95853.004 & .421 & .676 & tn \\
Amount of Sweep & 425278.608 & 2.086 & .043 & tn \\
Dead & $-1.534 \mathrm{E} 6$ & -3.745 & .001 & $*$ \\
Feed Costs & 4.913 & .455 & .052 & tn \\
Total Manpower & $2.570 \mathrm{E} 6$ & 4.903 & .000 & $*$ \\
\hline $\mathrm{R}^{2}$ & 0,53 & & & \\
F- count & 9,51 & & & \\
F table & 2,44 & & & \\
\hline
\end{tabular}

$\begin{array}{rll}\text { Information: } & * & =\text { real } \\ \text { tn } & =\text { not real }\end{array}$

To find out how far the ability of the model in explaining the variable variation in rabbit farmer's income can be seen from the value of the determination coefficient (R2). The analysis shows that the coefficient of determination for this model is 0.53 . This means that $53 \%$ of rabbit breeders' income is influenced by birth factors, weaning numbers, mortality, feed costs, and the number of workers. While $47 \%(100 \%-53 \%)$ are influenced by other factors that cannot be explained in this modeli.

Table 6 shows that this regression has a F-count of 9.51 while the F-table is 0.05 (2.44). Based on the decision criteria, Ha is accepted because F-count is greater than F-table. That means the variable litter size, weaning number, mortality, feed costs, and the number of workers together have a significant influence on the income of rabbit farmers.

\subsection{Rabbit Breeders Financial Analysis}

The financial analysis criteria chosen to find out the comparison between the amount of costs incurred with revenues are Revenue Cost Ratio (R / C), Benefit Cost Ratio (B / C) and Break Event Point (BEP).

Table 7. Financial Analysis of Rabbit Farmers in Berastagi District, Karo Regency

\begin{tabular}{ll}
\hline Criteria & Value \\
\hline R/C & 5,61 \\
B/C & 4,24 \\
BEP price & Rp 9.875 \\
BEP production & 22 tail \\
\hline
\end{tabular}


Results of Analysis of Revenue Cost Ratio

To see the level of economic benefits of rabbit farmers in Berastagi District, Karo Regency can be known by using Revenue Cost Ratio Analysis. R / C analysis is a comparison between revenue and costs. Table 7 shows that the $\mathrm{R} / \mathrm{C}$ value of 5.61> 1 means that farming of rabbit farmers in Berastagi District, Karo District, once the production process looks profitable.

Analysis of Benefit Cost Ratio

To see the level of business feasibility of rabbit farmers in Berastagi Subdistrict, Karo Regency can be found using Analysis of Benefit Cost Ratio. This analysis compares the net income with the net cost calculated at the present time. If the $\mathrm{B} / \mathrm{C}$ value is $>1$, then a feasible business is developed, but if the $\mathrm{B} / \mathrm{C}$ value is $<1$, then the business is not feasible to develop. Table 7 shows that the B / C value of 4.24> 1 means that farming of rabbit farmers in Berastagi District, Karo Regency is feasible to be developed.

Break Event Point Analysis Results

Break Even Point is a way to find out how much the volume of production and the determination of the lowest selling price so that farming to breed rabbits does not suffer losses, but in a position not to get profit (break even). Break-even analysis was used to determine the sale or production of rabbit cattle at the break-even position in rupiah units. Or to find out the break-even state (return of capital) obtained from the farm is known by calculating the BEP of Prices and Production. BEP Price $=$ IDR 9,875, BEP Production $=22$ heads.

BEP analysis shows the minimum production and price that must be achieved so that farming of rabbit breeders is at break-even point is 22 tails and the selling price of Rp. 9,875 / head. The production and price of rabbits in farming is clearly above break even.

\section{Conclusions}

The litter size $50 \%$ is $4-6$ rabbits, the sum of wean $58.33 \%$ is $4-6$ rabbits, the sum of deaths is $10.41 \%$ is $4-6$ rabbits, the feed cost $39.59 \%$ is $\mathrm{Rp} 20,000-100,000$ and the sum of labor $31.25 \%$ is 1-3 people. The results showed that the litter size, sum of wean, and feed cost did not affect the income of rabbit farmers while the sum of deaths and the sum of labors affected the income of rabbit farmers. Rabbit business in Berastagi Subdistrict, Karo Regency is profitable and feasible because of the analysis of Revenue Cost Ratio and Benefit Cost Ratio above 1. In addition, the percentage of rabbit farmer income in Berastagi District, Karo Regency reaches $75.14 \%$.

\section{References:}

[1] Cheeke, P.R., N.M. Patton, S.D. Lukefahr \& J.I. McNitt. 1987. Rabbit Production. 6th Edition. The Interstate Printers and Publishers, Inc., Danville. Illinois.

[2] Esminger, P. 1991. Marketing Management Analysis, Planning, Implements and Control. Alih Bahasa Ancell, A.H. Salemba Empat Prentice Hall. Jakarta.

[3] Hernawati, 2007. Perbaikan Kinerja reproduksi Akibat Pemberian Isoflavon dari Tanaman Kedelai. Jurusan Pendidikan Biologi FPMIPA Universitas Pendidikan Indonesia

[4] Key, R.D, dan Edward, W.M, 1994. Farm Management. Third Edition. Mc.Graw-Hill. Inc.Singapore.

[5] Sugiono, 2009. Metode Penelitian Kuantitatif, Kualitatif dan R\&D. CV.Alfabeta: Bandung. 